\title{
Essential and Toxic Metals in Infant Formula from the European Community
} \author{
Revert $^{3}$ and Arturo Hardisson ${ }^{1}$ \\ ${ }^{1}$ Área de Toxicología, Facultad de Ciencias de la Salud, Universidad de La Laguna, Spain \\ ${ }^{2}$ Servicio de Inspección Sanitaria y Laboratorio, Servicio Canario de la Salud, Spain \\ ${ }^{3}$ Área de Fisioterapia, Facultad de Ciencias de la Salud, Universidad de La Laguna, Spain
}

Alejandro Domínguez ${ }^{1}$, Soraya Paz ${ }^{1 *}$, Carmen Rubio ${ }^{1}$, Ángel Gutiérrez ${ }^{1}$, Dailos González-Weller², Consuelo

Submission: November 01, 2017; Published: December 13, 2017

*Corresponding author: Soraya Paz, Área de Toxicología, Facultad de Ciencias de la Salud, Universidad de La Laguna, Campus de Ofra s/n, 30071 Santa Cruz de Tenerife, Spain, Email: spazmont@gmail.com

\begin{abstract}
Infant formulas are intended for children aged 6 - 12 months who, for one reason or another, cannot be breastfed by their mother. These products are made to meet the nutritional needs of children and are therefore, required to be a source of essential metals. However, they may also contain non-essential and toxic metals from the raw material which they are made with and this may be a health risk to children. For this reason, the content of 19 metals ( $\mathrm{Na}, \mathrm{K}, \mathrm{Ca}, \mathrm{Mg}, \mathrm{Fe}, \mathrm{Cu}, \mathrm{Zn}, \mathrm{Cr}, \mathrm{B}, \mathrm{Ba}, \mathrm{Ni}, \mathrm{Li}, \mathrm{V}, \mathrm{Sr}, \mathrm{Mo}, \mathrm{Mn}, \mathrm{Al}, \mathrm{Cd}$, and Pb) were determined in a total of 30 infant formula samples from 15 different brands using inductively coupled plasma atomic emission optical spectroscopy (ICP-OES) with the objective of evaluating the nutritional profile and the toxicological risk derived from the consumption of these products. Ca was the major macroelement with a mean concentration of $4544 \mathrm{mg} / \mathrm{kg}$ wet weight. As regards trace elements, Fe stands out $(55.9 \mathrm{mg} / \mathrm{kg} \mathrm{ww})$. The mean concentration found for $\mathrm{Pb}(0.07 \mathrm{mg} / \mathrm{kg} \mathrm{ww})$ exceeds the maximum limit established in European legislation. The analyzed formulas cover the daily requirements of almost all essential elements. The intake of $\mathrm{Pb}$ from the consumption recommended by the manufacturer's means that lead contributes $233 \%$ of the Tolerable Daily Intake (TDI). Infant formulas meet the children's nutritional needs, although the concentration of Pb may pose a risk to children's health.
\end{abstract}

Keywords: Infant formula; Toxic metals; Dietary intake; Toxicological assessment; Toxic risk

\section{Introduction}

Breastfeeding is the main source of nutrients for infants since it meets nutritional needs, facilitating the growth and proper development of infants [1,2]. The composition of breast milk confers numerous benefits to the new-borns, reducing the risk of diseases such as enterocolitis or sepsis and strengthening the immune system of infants [2].

Although breast milk is the basis for infant feeding, there may be a number of situations that hinder breastfeeding, such as work, social reasons, medical contraindications or pharmacological treatments that cannot be replaced or withdrawn and pose a risk to the infant breast-feeder [3]. When these situations arise, an alternative diet should be used to meet the nutritional needs of infants, such as infant formulas or preparations. In particular, infant formulas are dairy milk substitutes for the mother's milk intended for children aged 6 to 12 months [4], which is a period when a supplementary feeding is started, and therefore these infant formulas do not need to completely meet the infants' nutritional requirements because this supplementary diet are also a source of nutrients [5].
The macroelements ( $\mathrm{Na}, \mathrm{K}, \mathrm{Ca}, \mathrm{Mg}$ ), are among the essential minerals required for a correct nutrition and are necessary in large quantities, as they play an important role in the human organism. For example, calcium (Ca), which is the major constituent of bone [6,7] or magnesium $(\mathrm{Mg})$, a metal of much importance for maintaining electrolytic balance [8]. On the other hand, trace elements or microelements ( $\mathrm{Fe}, \mathrm{Cu}, \mathrm{Cr}, \mathrm{Zn}$, $\mathrm{Mn}, \mathrm{Mo}$ and $\mathrm{Co}$ ) are required in smaller amounts but perform numerous physiological functions in the organism. As in the case of iron ( $\mathrm{Fe}$ ), which forms part of the hemoglobin necessary for the transport of oxygen [6,9], it is also added to infant formula to equalize its concentration with the mother's milk, or copper $(\mathrm{Cu})$, which plays an important role as a cofactor in enzymes intervening in multiple metabolic reactions [10].

Although infant formulas are beneficial and safe formulas, they may be a source of contaminants, such as trace elements with no function in the human organism ( $\mathrm{Sr}, \mathrm{Ni}, \mathrm{Li}, \mathrm{B}, \mathrm{Ba}$ and $\mathrm{V}$ ) or toxic metals ( $\mathrm{Al}, \mathrm{Cd}$ and $\mathrm{Pb}$ ), which tend to accumulate and are a health risk to children $[11,12]$, who are a more vulnerable 
group as their excretory capacity is lower than that of an adult, and their body weight is less and they have a weaker immune system [13].

High intakes of non-essential trace elements have toxic effects on health, such as strontium (Sr) for example, which can interfere in numerous biological processes which calcium participates in, due to its affinity for this element, which can lead to childhood rickets [14]. Besides which, Sr can produce insoluble compounds with phosphorus (P) leading to phosphorus deficiency $[15,16]$. However, there are no known cases of intoxication from these metals arising from diet.

Toxic metals tend to accumulate in the human organism causing multiple toxic effects. Aluminum (Al), a neurotoxic agent, has an affinity for the brain where it accumulates and can cause damage to the central nervous system (CNS). Numerous studies have linked high concentrations of $\mathrm{Al}$ in the brain with memory loss and neurodegenerative diseases such as Alzheimer's or Parkinson's [17,18]. Cadmium (Cd) and lead $(\mathrm{Pb})$ are characterized by a high half-life and by their tendency to accumulate in different parts of the body. Excessive intake of $\mathrm{Cd}$ and $\mathrm{Pb}$ can lead to cardiovascular disease, damage to the nervous system and the bones [19-21].

Since infant formulas are intended for growing children, they need to be safe and meet the nutritional needs of the target population. Therefore, the objectives of this study are to determine the content of macroelements ( $\mathrm{Na}, \mathrm{K}, \mathrm{Ca}$ and $\mathrm{Mg}$ ) and essential elements ( $\mathrm{Fe}, \mathrm{Cu}, \mathrm{Zn}, \mathrm{Cr}, \mathrm{Mn}$ and $\mathrm{Mo}$ ) in infant formulas to evaluate the nutritional profile as well as the content of nonessential metals (B, Ba, $\mathrm{Li}, \mathrm{Ni}, \mathrm{V}$ and $\mathrm{Sr}$ ) and toxic metals ( $\mathrm{Al}, \mathrm{Cd}$ and $\mathrm{Pb}$ ) in order to evaluate the toxicological risk derived from the consumption of these products, taking into account the maximum intake limits and the established legislation.

\section{Materials and methods}

\section{Samples}

Table 1: Characteristics of analyzed the powered infant formula samples.

\begin{tabular}{|c|c|c|c|c|c|c|}
\hline Identification & Class & Protein source & Age group & No. Samples & Format & Type of container \\
\hline M1 & Enriched formula & Cow's milk & 6-12 months & 2 & $800 \mathrm{~g}$ & Paper bag \\
\hline M2 & Enriched formula & Cow's milk & 6-12 months & 2 & $400 \mathrm{~g}$ & Aluminium tin \\
\hline M3 & Enriched formula & Cow's milk & 6-12 months & 2 & $800 \mathrm{~g}$ & Aluminium tin \\
\hline M4 & Enriched formula & Cow's milk & 6-12 months & 2 & $800 \mathrm{~g}$ & Aluminium tin \\
\hline M5 & Enriched formula & Cow's milk & 6-12 months & 2 & $800 \mathrm{~g}$ & Aluminium tin \\
\hline M6 & Enriched formula & Cow's milk & 6-12 months & 2 & $800 \mathrm{~g}$ & Aluminium tin \\
\hline M7 & Enriched formula & Cow's milk & 6-12 months & 2 & $800 \mathrm{~g}$ & Aluminium tin \\
\hline M8 & Enriched formula & Cow's milk & 6-12 months & 2 & $800 \mathrm{~g}$ & Aluminium tin \\
\hline M9 & Enriched formula & Cow's milk & 6-12 months & 2 & $800 \mathrm{~g}$ & Aluminium tin \\
\hline M10 & Enriched formula & Cow's milk & 6-12 months & 2 & $800 \mathrm{~g}$ & Aluminium tin \\
\hline M11 & Enriched formula & Cow's milk & 6-12 months & 2 & $800 \mathrm{~g}$ & Aluminium tin \\
\hline M12 & Enriched formula & Cow's milk & 6-12 months & 2 & $800 \mathrm{~g}$ & Aluminium tin \\
\hline M13 & Soya based formula & Soy & 6-12 months & 2 & $400 \mathrm{~g}$ & Aluminium tin \\
\hline M14 & Hydrolyzed formula & $\begin{array}{l}\text { Extensively } \\
\text { hydrolysed }\end{array}$ & 6-12 months & 2 & $800 \mathrm{~g}$ & Aluminium tin \\
\hline M15 & Hypoallergenic formula & $\begin{array}{l}\text { Extensively } \\
\text { hydrolysed }\end{array}$ & 6-12 months & 2 & $800 \mathrm{~g}$ & Aluminium tin \\
\hline
\end{tabular}

A total of 30 samples of different types of powdered infant formulas with 15 different brand names, for infants aged between 6 and 12 months, were analyzed. Table 1 shows the characteristics of the samples analyzed.

The samples were purchased in pharmacies on the island of Tenerife (Canary Islands, Spain) between December 2016 and
March 2017. They were stored in their original containers until they were opened.

\section{Treatment of samples and analysis}

Five grams of each previously homogenized sample were weighed in triplicate in porcelain crucibles (Staatlich, Germany). 
They were dried in an oven (Nabertherm, Germany) for 24 hours at $70-80{ }^{\circ} \mathrm{C}$. They were then subjected to acid digestion with $65 \% \mathrm{HNO}_{3}$ of reagent purity (Honeybell Fluka, Germany). After digestion, the capsules were placed in a muffle furnace (Nabertherm, Germany) with a time-temperature program of $425{ }^{\circ} \mathrm{C}-24$ hours, with a gradual rise in temperature of 50 ${ }^{\circ} \mathrm{C} /$ hour. The white or greyish white ashes were dissolved in $1.5 \%$ nitric acid $\left(\mathrm{HNO}_{3}\right)$ and transferred to sterile, hermetic polyethylene containers $[7,10,22]$. The determination of the metals was performed in a period of less than two weeks after their preparation.

The metal content was determined by inductively coupled plasma atomic emission optical spectroscopy (ICP-OES) using a Thermo Scientific iCAP 6000 series spectrometer (Waltham, MA, USA). The instrumental conditions were as follows: approximate RF power of $1.2 \mathrm{~kW}$, gas flow (nebulizer flow, auxiliary flow) of $0.5 \mathrm{~L} / \mathrm{min}$, pump speed of 50rpm, stabilization time of 0 seconds, wavelength (nm) of each metal: Al (167), B (249.7), Ba (455.4), Ca (317.9), Cd (226.5), Cr (267.7), Cu (327.3), Fe (259.9), K (769.9), Li (670.8), Mg (279.1), Mn (257.6), Mo (202.0), Na (589.6), Ni (231.6), Pb (220.3), Sr (407.7), V (310.2), Zn (206.2).

The quantification limits of the metals were calculated as ten times the standard deviation (SD) obtained from the analysis of 15 targets under reproducible conditions [23], and were as follows: $0.012 \mathrm{mg} / \mathrm{L}(\mathrm{Al}), 0.012 \mathrm{mg} / \mathrm{L}(\mathrm{B}), 0.005 \mathrm{mg} / \mathrm{L}$ (Ba), $1.995 \mathrm{mg} / \mathrm{L} \quad(\mathrm{Ca}), \quad 0.001 \mathrm{mg} / \mathrm{L} \quad(\mathrm{Cd}), 0.008 \mathrm{mg} / \mathrm{L} \quad(\mathrm{Cr})$, $0.012 \mathrm{mg} / \mathrm{L}(\mathrm{Cu}), 0.009 \mathrm{mg} / \mathrm{L}(\mathrm{Fe}), 1.884 \mathrm{mg} / \mathrm{L}(\mathrm{K}), 0.013 \mathrm{mg} / \mathrm{L}$ (Li), $1.943 \mathrm{mg} / \mathrm{L}(\mathrm{Mg}), \quad 0.008 \mathrm{mg} / \mathrm{L}(\mathrm{Mn}), \quad 0.002 \mathrm{mg} / \mathrm{L} \quad(\mathrm{Mo})$, $3.655 \mathrm{mg} / \mathrm{L}(\mathrm{Na}), 0.003 \mathrm{mg} / \mathrm{L}(\mathrm{Ni}), 0.001 \mathrm{mg} / \mathrm{L}(\mathrm{Pb}), 0.003 \mathrm{mg} / \mathrm{L}$ (Sr), $0.005 \mathrm{mg} / \mathrm{L}(\mathrm{V}), 0.007 \mathrm{mg} / \mathrm{L}(\mathrm{Zn})$.

In order to ensure the accuracy and precision of the analytical method, a quality control was carried out based on the recovery rate obtained after subjecting the certified reference materials, similar to the matrix under study, to the same treatment procedure as the samples. The reference materials used were BCR-150 and BCR-063R Skim Milk Powder, from the Institute for Reference Materials and Measurements (IRMM), and 1549 NonFat Milk Powder from the National Institute of Standards and Technology (NIST). All recovery rates were higher than $98 \%$, and no significant differences $(p=0)$ were found between the certified concentration and the concentration obtained.

\section{Statistical analysis}

The statistical analysis was conducted with the IBM Statistics SPSS software for Mac ${ }^{\mathrm{TM}}$. First, a normality study was carried out to determine whether the data followed a normal distribution or not by applying the Kolmogorov-Smirnov and Shapiro-Wilk tests [24]. The data which did not follow a normal distribution were analysed by nonparametric tests using the Kruskal-Wallis test [25].

These studies were carried out to study the possible existence of significant differences in the metal content among the different brands of infant formula studied. Values of $\mathrm{p}<0.05$ were considered significantly different.

\section{Results}

Table 2: Mean metal content and standard deviation found in the analyzed samples without differentiating by brand.

\begin{tabular}{|c|c|}
\hline Metal & Mean concentration $(\mathrm{mg} / \mathrm{kg}$ wet weight $) \pm \mathrm{SD}$ \\
\hline \multicolumn{2}{|r|}{ Macroelements } \\
\hline K & $4107 \pm 264$ \\
\hline $\mathrm{Mg}$ & $441 \pm 16.5$ \\
\hline $\mathrm{Na}$ & $1668 \pm 88.7$ \\
\hline $\mathrm{Ca}$ & $4544 \pm 318$ \\
\hline \multicolumn{2}{|r|}{ Trace elements } \\
\hline $\mathrm{Cr}$ & $0.13 \pm 0.02$ \\
\hline $\mathrm{Cu}$ & $3.75 \pm 0.40$ \\
\hline $\mathrm{Fe}$ & $55.9 \pm 7.55$ \\
\hline $\mathrm{Zn}$ & $34.2 \pm 1.09$ \\
\hline $\mathrm{Mn}$ & $1.00 \pm 0.23$ \\
\hline Mo & $0.14 \pm 0.01$ \\
\hline $\mathrm{V}$ & $0.28 \pm 0.16$ \\
\hline $\mathrm{Ni}$ & $0.07 \pm 0.04$ \\
\hline $\mathrm{Li}$ & $0.96 \pm 0.44$ \\
\hline $\mathrm{Sr}$ & $2.47 \pm 0.95$ \\
\hline $\mathrm{Ba}$ & $1.20 \pm 0.42$ \\
\hline B & $1.59 \pm 0.21$ \\
\hline \multicolumn{2}{|r|}{ Toxic metals } \\
\hline $\mathrm{Al}$ & $4.02 \pm 2.01$ \\
\hline $\mathrm{Cd}$ & $0.01 \pm 0.00$ \\
\hline $\mathrm{Pb}$ & $0.07 \pm 0.02$ \\
\hline
\end{tabular}

Table 2 shows the mean concentrations ( $\mathrm{mg} / \mathrm{kg}$ wet weight) of each metal studied and their obtained standard deviations for all samples without taking the brand into account.

$\mathrm{Ca}$ is the major macroelement, with a mean concentration of $4544 \mathrm{mg} / \mathrm{kg}$ ww wet weight, the remaining macroelements follow the sequence $\mathrm{K}(4107 \mathrm{mg} / \mathrm{kg} \mathrm{ww})>\mathrm{Na}(1668 \mathrm{mg} / \mathrm{kg} \mathrm{ww})>$ $\mathrm{Mg}$ (441mg/kg ww).As for the essential trace elements, the concentrations of Fe $(55.9 \mathrm{mg} / \mathrm{kg} \mathrm{ww})$ and $\mathrm{Zn}(34.2 \mathrm{mg} / \mathrm{kg} \mathrm{ww})$ are noteworthy. The mean concentration of $\mathrm{Sr}$ at $2.47 \mathrm{mg} / \mathrm{kg} \mathrm{ww}$ is worth mentioning in the case of non-essential trace elements.

$\mathrm{Al}$ is the toxic metal with the highest mean concentration of $4.02 \mathrm{mg} / \mathrm{kg} w w$, followed by $\mathrm{Pb}(0.07 \mathrm{mg} / \mathrm{kg} w \mathrm{w})$ and $\mathrm{Cd}$ $(0.01 \mathrm{mg} / \mathrm{kg} \mathrm{ww})$. It should be noted that the mean level of $\mathrm{Pb}$ 
found was above the maximum limit of $0.02 \mathrm{mg} / \mathrm{kg}$ fresh weight for powdered infant formula established by Regulation (EC) No 1881/2006 of 19 December 2006 which sets the maximum content of certain contaminants in foodstuffs [26].

In addition, Regulation (EU) No 488/2014 amending Regulation (EC) No 1881/2006 sets a maximum limit of $0.01 \mathrm{mg} /$ $\mathrm{kg}$ fresh weight for powdered infant formula made from protein obtained from cows' milk or from protein hydrolysates, and of $0.02 \mathrm{mg} / \mathrm{kg}$ fresh weight for infant formula prepared from soy protein either alone or in combination with cow's milk [27]. Therefore, the mean Cd concentration found reaches the maximum limit established in the legislation.

Studies conducted by Kazi et al. [28] and by WiniarskaMieczan [13] report $\mathrm{Pb}$ and $\mathrm{Cd}$ concentrations in infant formulas similar to the results obtained here. Although Pandelova et al. [29] found higher Cd levels than those in the present study.

It is noteworthy that both the $\mathrm{Pb}$ and $\mathrm{Cd}$ levels found in human milk are lower than those recorded in the infant formula studied [30]. However, levels of contaminants in breast milk depend on diet, environment, and habits, with higher levels of both metals being found in female smokers or in those living in contaminated areas [31].

\section{Metal content obtained in each brand studied}

Table 3 shows the concentrations of macroelements and essential trace elements ( $\mathrm{mg} / \mathrm{kg}$ wet weight) and their standard deviations obtained depending on the infant formula brand studied.

Table 3: Macroelement and trace element content ( $\mathrm{mg} / \mathrm{kg}$ wet weight) and standard deviation found in each analyzed brand.

\begin{tabular}{|c|c|c|c|c|c|c|c|c|c|c|}
\hline \multicolumn{11}{|c|}{ Concentration $(\mathrm{mg} / \mathrm{kg} \mathrm{ww}) \pm$ Standard Deviation } \\
\hline \multirow{2}{*}{ Sample } & \multicolumn{4}{|c|}{ Macroelements } & \multicolumn{6}{|c|}{ Trace elements } \\
\hline & $\mathrm{Ca}$ & $\mathrm{K}$ & $\mathrm{Mg}$ & $\mathrm{Na}$ & $\mathrm{Fe}$ & $\mathrm{Cu}$ & $\mathrm{Cr}$ & $\mathrm{Mn}$ & Mo & $\mathrm{Zn}$ \\
\hline M1 & $3286 \pm 281$ & $3052 \pm 26.6$ & $398 \pm 12.7$ & $398 \pm 12.7$ & $41.9 \pm 10.4$ & $2.76 \pm 0.54$ & $0.11 \pm 0.02$ & $0.84 \pm 0.15$ & $0.10 \pm 0.02$ & $28.9 \pm 4.87$ \\
\hline M2 & $4559 \pm 257$ & $4520 \pm 137$ & $454 \pm 18.9$ & $454 \pm 18.9$ & $67.4 \pm 7.22$ & $4.01 \pm 0.44$ & $0.14 \pm 0.01$ & $2.02 \pm 0.07$ & $0.23 \pm 0.01$ & $38.1 \pm 0.97$ \\
\hline M3 & $4773 \pm 455$ & $4306 \pm 360$ & $417 \pm 6.07$ & $417 \pm 6.07$ & $62.8 \pm 12.3$ & $4.02 \pm 0.37$ & 0.140 .02 & $0.43 \pm 0.03$ & $0.07 \pm 0.01$ & $38.0 \pm 1.14$ \\
\hline M4 & $5221 \pm 348$ & $4403 \pm 131$ & $457 \pm 21.1$ & $457 \pm 21.1$ & $57.5 \pm 10.8$ & $4.38 \pm 0.28$ & $0.12 \pm 0.01$ & $0.55 \pm 0.03$ & $0.09 \pm 0.01$ & $38.1 \pm 0.84$ \\
\hline M5 & $5117 \pm 149$ & $4411 \pm 166$ & $581 \pm 15.8$ & $581 \pm 15.8$ & $60.1 \pm 1.02$ & $3.01 \pm 0.03$ & $0.16 \pm 0.01$ & $0.96 \pm 0.02$ & $0.19 \pm 0.00$ & $35.5 \pm 0.40$ \\
\hline M6 & $3043 \pm 92.0$ & $4091 \pm 90.9$ & $405 \pm 11.6$ & $405 \pm 11.6$ & $35.6 \pm 0.86$ & $3.56 \pm 0.10$ & $0.08 \pm 0.01$ & $0.87 \pm 0.01$ & $0.04 \pm 0.01$ & $36.4 \pm 0.52$ \\
\hline M7 & $4341 \pm 198$ & $3650 \pm 106$ & $314 \pm 35.4$ & $314 \pm 35.4$ & $51.2 \pm 6.13$ & $3.41 \pm 0.17$ & $0.13 \pm 0.02$ & $0.46 \pm 0.01$ & $0.14 \pm 0.00$ & $27.4 \pm 0.99$ \\
\hline M8 & $5527 \pm 387$ & $4352 \pm 295$ & $419 \pm 21.4$ & $419 \pm 21.4$ & $41.1 \pm 6.89$ & $3.61 \pm 0.29$ & $0.13 \pm 0.01$ & $0.36 \pm 0.02$ & $0.07 \pm 0.01$ & $33.2 \pm 0.22$ \\
\hline M9 & $4628 \pm 493$ & $4162 \pm 378$ & $369 \pm 2.98$ & $369 \pm 2.98$ & $48.0 \pm 9.76$ & $3.61 \pm 0.77$ & $0.12 \pm 0.02$ & $0.48 \pm 0.05$ & $0.07 \pm 0.01$ & $37.2 \pm 1.49$ \\
\hline M10 & $4981 \pm 260$ & $4462 \pm 320$ & $448 \pm 44.2$ & $448 \pm 44.3$ & $53.5 \pm 3.38$ & $3.72 \pm 0.38$ & $0.13 \pm 0.03$ & $1.04 \pm 0.10$ & $0.11 \pm 0.01$ & $34.5 \pm 1.22$ \\
\hline M11 & $4375 \pm 208$ & $34256 \pm 240$ & $548 \pm 17.7$ & $548 \pm 17.7$ & $53.9 \pm 1.50$ & $3.85 \pm 0.31$ & $0.10 \pm 0.01$ & $0.96 \pm 0.13$ & $0.19 \pm 0.01$ & $37.3 \pm 0.89$ \\
\hline M12 & $4483 \pm 471$ & $4314 \pm 412$ & $577 \pm 10.4$ & $577 \pm 10.4$ & $65.5 \pm 12.6$ & $4.08 \pm 0.62$ & $0.13 \pm 0.04$ & $0.72 \pm 0.05$ & $0.17 \pm 0.02$ & $42.8 \pm 0.61$ \\
\hline M13 & $4454 \pm 543$ & $4391 \pm 598$ & $502 \pm 11.5$ & $502 \pm 11.5$ & $68.9 \pm 14.0$ & $2.99 \pm 0.53$ & $0.18 \pm 0.03$ & $2.20 \pm 0.41$ & $0.35 \pm 0.05$ & $27.0 \pm 0.91$ \\
\hline M14 & $5417 \pm 158$ & $4060 \pm 195$ & $302 \pm 9.75$ & $302 \pm 9.75$ & $65.9 \pm 2.12$ & $4.66 \pm 0.78$ & $0.13 \pm 0.01$ & $1.27 \pm 1.11$ & $0.26 \pm 0.01$ & $27.1 \pm 0.28$ \\
\hline M15 & $3960 \pm 465$ & $4005 \pm 497$ & $419 \pm 7.57$ & $419 \pm 7.57$ & $65.5 \pm 14.3$ & $4.58 \pm 0.45$ & $0.11 \pm 0.02$ & $1.79 \pm 1.24$ & $0.06 \pm 0.01$ & $32.1 \pm 0.96$ \\
\hline
\end{tabular}

As for macroelements, the highest concentrations of $\mathrm{Ca}$ found in the branded formulas were in M8 $(5527 \mathrm{mg} / \mathrm{kg} \mathrm{ww})$ and M14 (5417mg/kg ww). The highest level of K was in M2, with a concentration of $4520 \mathrm{mg} / \mathrm{kg}$ ww. Whereas the highest $\mathrm{Mg}$ and Na concentrations were observed in M5 (581mg/kg ww) and M13 (2061 mg/kg ww), respectively. 
As regards the essential trace elements, the Fe level determined in the samples of the M1368.9mg/kg wwis noteworthy as are the $\mathrm{Zn}$ contents in the M2 and M4samples, with both being $38.1 \mathrm{mg} / \mathrm{kg}$ ww.

Table 4 shows the mean concentrations ( $\mathrm{mg} / \mathrm{kg}$ wet weight) and standard deviations of the non-essential trace elements and toxic metals found for each analyzed brand.

$\mathrm{Sr}$ is the most notable trace element with an average concentration of $5.26 \mathrm{mg} / \mathrm{kg}$ ww, with the highest concentration being found in M10. Furthermore, it is worth mentioning the mean levels of B and Li found in the M14 were $3.21 \mathrm{mg} / \mathrm{kg} \mathrm{ww}$ and $2.84 \mathrm{mg} / \mathrm{kg} w \mathrm{w}$, respectively. The statistical analysis confirmed the existence of significant differences in the vanadium content between the different samples analyzed, with the highest mean concentration being determined in M2.

Regarding toxic metals, M7 had the highest level of aluminium which was $7.05 \mathrm{mg} / \mathrm{kg}$ ww. Besides, the $\mathrm{Pb}$ concentration found in M1 is noteworthy, with a mean concentration of $0.09 \mathrm{mg} / \mathrm{kg}$ ww. The Cd levels, however, were similar in all the analyzed brands, with the exception of M13, whose Cd concentration was the highest with a mean value of $0.02 \mathrm{mg} / \mathrm{kg}$ ww. This higher concentration of $\mathrm{Cd}$ can be explained by the fact that M13 corresponds to the soybean-based infant formula, and that the soybean has the capacity to absorb toxic metals from the soil [32].

Table 4: Non-essential trace element and toxic metal content ( $\mathrm{mg} / \mathrm{kg}$ wet weight) and standard deviation found in each analyzed brand.

\begin{tabular}{|c|c|c|c|c|c|c|c|c|c|}
\hline \multicolumn{10}{|c|}{ Concentration $(\mathrm{mg} / \mathrm{kg} \mathrm{ww}) \pm$ Standard Deviation } \\
\hline \multirow{2}{*}{ Sample } & \multicolumn{6}{|c|}{ Non-essential trace elements } & \multicolumn{3}{|c|}{ Toxic metals } \\
\hline & $\mathrm{B}$ & $\mathrm{Ba}$ & $\mathrm{V}$ & $\mathrm{Ni}$ & $\mathrm{Li}$ & $\mathrm{Sr}$ & $\mathrm{Al}$ & $\mathrm{Cd}$ & $\mathrm{Pb}$ \\
\hline M1 & $0.93 \pm 0.14$ & $0.63 \pm 0.16$ & $0.18 \pm 0.32$ & $0.05 \pm 0.02$ & $0.54 \pm 0.35$ & $1.63 \pm 0.18$ & $2.79 \pm 0.85$ & $0.01 \pm 0.00$ & $0.09 \pm 0.01$ \\
\hline M2 & $1.27 \pm 0.12$ & $2.26 \pm 0.63$ & $0.64 \pm 0.64$ & $0.10 \pm 0.01$ & $1.52 \pm 0.51$ & $1.95 \pm 0.06$ & $5.92 \pm 1.74$ & $0.01 \pm 0.00$ & $0.07 \pm 0.01$ \\
\hline M3 & $1.64 \pm 0.19$ & $1.43 \pm 0.37$ & $0.24 \pm 0.19$ & $0.04 \pm 0.01$ & $1.33 \pm 0.43$ & $1.66 \pm 0.10$ & $2.71 \pm 1.76$ & $0.01 \pm 0.00$ & $0.06 \pm 0.01$ \\
\hline M4 & $1.57 \pm 0.09$ & $1.49 \pm 0.70$ & $0.28 \pm 0.08$ & $0.05 \pm 0.02$ & $1.32 \pm 0.30$ & $1.63 \pm 0.06$ & $6.63 \pm 2.15$ & $0.01 \pm 0.00$ & $0.08 \pm 0.01$ \\
\hline M5 & $1.38 \pm 0.10$ & $0.92 \pm 0.37$ & $0.19 \pm 0.19$ & $0.04 \pm 0.01$ & $0.76 \pm 0.50$ & $2.08 \pm 0.16$ & $2.76 \pm 0.63$ & $0.01 \pm 0.00$ & $0.05 \pm 0.01$ \\
\hline M6 & $1.14 \pm 0.05$ & $0.39 \pm 0.04$ & $0.13 \pm 0.03$ & $0.04 \pm 0.01$ & $0.42 \pm 0.05$ & $2.72 \pm 1.19$ & $1.87 \pm 1.23$ & $0.01 \pm 0.00$ & $0.06 \pm 0.01$ \\
\hline M7 & $1.24 \pm 0.40$ & $0.51 \pm 0.07$ & $0.25 \pm 0.12$ & $0.06 \pm 0.02$ & $0.42 \pm 0.03$ & $3.63 \pm 1.59$ & $7.05 \pm 7.30$ & $0.01 \pm 0.00$ & $0.08 \pm 0.04$ \\
\hline M8 & $1.25 \pm 0.08$ & $0.68 \pm 0.36$ & $0.24 \pm 0.15$ & $0.02 \pm 0.01$ & $0.31 \pm 0.03$ & $1.78 \pm 0.13$ & $1.58 \pm 0.76$ & $0.01 \pm 0.00$ & $0.06 \pm 0.00$ \\
\hline M9 & $1.14 \pm 0.25$ & $1.12 \pm 0.46$ & $0.10 \pm 0.10$ & $0.07 \pm 0.00$ & $0.84 \pm 0.70$ & $1.39 \pm 0.07$ & $4.68 \pm 2.20$ & $0.01 \pm 0.00$ & $0.07 \pm 0.03$ \\
\hline M10 & $1.17 \pm 0.09$ & $1.36 \pm 0.26$ & $0.24 \pm 0.11$ & $0.04 \pm 0.02$ & $0.79 \pm 0.55$ & $5.26 \pm 3.47$ & $4.01 \pm 3.94$ & $0.01 \pm 0.00$ & $0.08 \pm 0.03$ \\
\hline M11 & $1.43 \pm 0.37$ & $1.83 \pm 1.07$ & $0.29 \pm 0.12$ & $0.25 \pm 0.37$ & $0.41 \pm 0.19$ & $2.00 \pm 0.64$ & $2.08 \pm 0.50$ & $0.01 \pm 0.00$ & $0.06 \pm 0.01$ \\
\hline M12 & $2.18 \pm 0.25$ & $1.40 \pm 0.63$ & $0.27 \pm 0.08$ & $0.06 \pm 0.01$ & $0.78 \pm 0.29$ & $1.12 \pm 0.11$ & $4.25 \pm 3.42$ & $0.01 \pm 0.00$ & $0.07 \pm 0.02$ \\
\hline M13 & $2.71 \pm 0.51$ & $1.44 \pm 0.63$ & $0.35 \pm 0.07$ & $0.12 \pm 0.01$ & $0.61 \pm 0.07$ & $3.60 \pm 1.32$ & $3.72 \pm 0.44$ & $0.02 \pm 0.00$ & $0.06 \pm 0.00$ \\
\hline M14 & $3.21 \pm 0.13$ & $1.51 \pm 0.37$ & $0.37 \pm 0.11$ & $0.05 \pm 0.01$ & $2.84 \pm 1.39$ & $3.68 \pm 2.71$ & $6.23 \pm 0.42$ & $0.01 \pm 0.00$ & $0.07 \pm 0.03$ \\
\hline M15 & $1.57 \pm 0.42$ & $1.05 \pm 0.16$ & $0.40 \pm 0.05$ & $0.05 \pm 0.00$ & $1.57 \pm 1.18$ & $2.98 \pm 2.51$ & $4.00 \pm 2.75$ & $0.01 \pm 0.00$ & $0.08 \pm 0.03$ \\
\hline
\end{tabular}

\section{Discussion}

The daily consumption of infant formula recommended by the manufacturers studied is about 150 grams of milk powder per day. The recommended consumption and the mean concentrations obtained for each metal were taken into account to calculate the estimated daily intake (EDI), as well as its contribution to the recommended daily intake (RDI) and the maximum intake for the infant formulas (Table 5).

Table 5: Estimated daily intake (EDI) and percentage contribution to the maximum and recommended daily intake for each analyzed metal.

\begin{tabular}{|c|c|c|c|c|}
\hline \multicolumn{5}{|c|}{ Macro elements and essential trace elements } \\
\hline & Mean conc. $(\mathrm{mg} / \mathrm{kg}) \pm \mathrm{SD}$ & EDI (mg/day) ${ }^{a}$ & Recommended Daily Intake (RDI) & Contribution $(\%)^{b}$ \\
\hline $\mathrm{Na}$ & $1668 \pm 88.7$ & 616 & $370 \mathrm{mg} /$ day [33] & 88 \\
\hline $\mathrm{K}$ & $4107 \pm 264$ & 66.2 & $700 \mathrm{mg} /$ day [33] & 88.2 \\
\hline $\mathrm{Ca}$ & $1668 \pm 88.7$ & 250 & $525 \mathrm{mg} /$ day [33] & 67.6 \\
\hline $\mathrm{Mg}$ & $441 \pm 16.5$ & 682 & 75 mg/day [33] & 130 \\
\hline $\mathrm{Cr}$ & $0.13 \pm 0.02$ & 0.02 & $5.5 \mu \mathrm{g} /$ day $[6]$ & 355 \\
\hline $\mathrm{Cu}$ & $3.75 \pm 0.40$ & 0.56 & $0.3 \mu \mathrm{g} /$ day [33] & 188 \\
\hline $\mathrm{Fe}$ & $55.9 \pm 7.55$ & 8.39 & 8 mg/day [33] & 105 \\
\hline $\mathrm{Zn}$ & $34.2 \pm 1.09$ & 5.13 & 4 mg/day [33] & 128 \\
\hline
\end{tabular}


Open Access Journal of Toxicology

\begin{tabular}{|c|c|c|c|c|}
\hline $\mathrm{Mn}$ & $1.00 \pm 0.23$ & 0.15 & $0.6 \mathrm{mg} /$ day [33] & 25 \\
\hline Mo & $0.14 \pm 0.01$ & 0.02 & $3 \mu \mathrm{g} /$ day [33] & 700 \\
\hline \multicolumn{5}{|c|}{ Toxic and non-essential elements } \\
\hline & Mean conc. $(\mathrm{mg} / \mathrm{kg}) \pm \mathrm{SD}$ & EDI (mg/day)a & Maximum values (TDI or TWI) & Contribution $(\%) \mathrm{b}$ \\
\hline $\mathrm{Ni}$ & $0.07 \pm 0.04$ & 0.01 & $2.8 \mu \mathrm{g} / \mathrm{kg}$ bw/day [37] & 41.7 \\
\hline $\mathrm{Sr}$ & $2.47 \pm 0.95$ & 0.37 & $0.13 \mathrm{mg} / \mathrm{kg}$ bw/day [39] & 31.7 \\
\hline $\mathrm{Ba}$ & $1.20 \pm 0.42$ & 0.18 & $200 \mu \mathrm{g} / \mathrm{kg}$ bw/day [38] & 100 \\
\hline B & $1.59 \pm 0.21$ & 0.24 & $0.16 \mathrm{mg} / \mathrm{kg}$ bw/day [38] & 16.6 \\
\hline $\mathrm{Al}$ & $4.02 \pm 2.01$ & 0.6 & $1 \mathrm{mg} / \mathrm{kg}$ bw/week [35] & 46.9 \\
\hline $\mathrm{Cd}$ & $0.01 \pm 0.00$ & 0.002 & $2.5 \mu \mathrm{g} / \mathrm{kg}$ bw/week [34] & 46.7 \\
\hline $\mathrm{Pb}$ & $0.07 \pm 0.02$ & 0.01 & $0.5 \mu \mathrm{g} / \mathrm{kg}$ bw/day $[40]$ & 233 \\
\hline \multicolumn{5}{|c|}{$\begin{array}{c}{ }^{\mathrm{a} C a l c u l a t e d} \text { as EDI=Metal concentration }(\mathrm{mg} / \mathrm{kgww}) \bullet \text { Mean consumption }(\mathrm{kg} / \text { day)., based on a mean consumption of } 150 \text { grams a day } \\
{ }^{\mathrm{b} C a l c u l a t e d} \text { as Contribution }(\%)=(\mathrm{EDI}(\mathrm{mg} / \mathrm{day})) /(\mathrm{RDI} \text { or Maximum values }) \bullet 100 \text {, based on a mean body weight of } 9 \text { kilos in the case of TDI an } \\
\text { TWI }\end{array}$} \\
\hline
\end{tabular}

The Recommended Daily Intake (RDI) values for macroelements and essential trace elements for children aged 7-12 months, established by FESNAD (the Spanish Federation of Nutrition, Food and Dietetic Societies), are as follows: $525 \mathrm{mg}$ $\mathrm{Ca}$ /day, 700mg K/day, 75mg mg/day, 370mg Na/day, 8mg Fe/ day, $4 \mathrm{mg} \mathrm{Zn/day,} 0.3 \mu \mathrm{g} \mathrm{Cu} /$ day, $0.6 \mathrm{mg} \mathrm{Mn/day,} 3 \mu \mathrm{g}$ Mo/day [33], and for chromium set at $5.5 \mu \mathrm{g} \mathrm{Cr} /$ day by the Institute of Medicine, Food and Nutrition Board [6].

In view of the results presented in Table 4 , the contribution of macroelements from the consumption of the infant formulas studied meets the nutritional requirements of infants from 7 to 12 months of age, with the noteworthy contribution of calcium, which accounts for $129 \%$ of RDI, followed by $\mathrm{Mg}$, K and $\mathrm{Na}$, with contribution rates of $88.1 \%, 88.0 \%$ and $68.0 \%$, respectively. As regards the essential trace elements, the nutritional needs of infants are met, exceeding $100 \%$ of the RDI for all metals, with the exception of $\mathrm{Mn}$, whose contribution is $25 \%$ of the recommended daily intake. However, it must be taken into account that at these ages, the infants start other foods that contribute to nutritional requirements.

In order to evaluate the toxic risk derived from the consumption of these products, a mean body weight of $9 \mathrm{~kg}$ was used, as well as tolerable daily intake (TDI) or tolerable daily weekly intake (TWI) values established by various institutions, such as:

1. The European Food Safety Authority (EFSA) sets the following tolerable weekly intakes (TWI) for cadmium of $2.5 \mu \mathrm{g} \mathrm{Cd} / \mathrm{kg}$ body weight/week [34] and for aluminium of $1 \mathrm{mg} \mathrm{Al} / \mathrm{kg}$ body weight/week [35] as well as the following tolerable daily intakes for chromium of $0.3 \mathrm{mg} \mathrm{Cr} / \mathrm{kg}$ body weight/day [36] and for nickel of $2.8 \mu \mathrm{g} \mathrm{Ni} / \mathrm{kg}$ body weight/ day [37].

2. World Health Organization (WHO) sets the following tolerable daily intakes for boron of $0.16 \mathrm{mg} \mathrm{B} / \mathrm{kg}$ body weight/day, for barium $0.02 \mathrm{mg} \mathrm{Ba/kg}$ body weight/day [38] and for strontium of $0.13 \mathrm{mg} \mathrm{Sr} / \mathrm{kg}$ body weight/day [39].

3. The Spanish Agency for Food Safety and Nutrition (AESAN) has suggested a lead TDI of $0.5 \mu \mathrm{g} / \mathrm{kg}$ body weight/day [40], adapted from BMDL01 (Benchmark dose modelling) dosage set by the EFSA [41].

The contribution percentages obtained for non-essential trace elements and for toxic metals (Table 5) are below tolerable daily and admissible weekly daily intake values, with the exception of barium and lead. In the case of barium, a percentage of contribution that is $100 \%$ of the TDI was observed, in spite of this, no cases of intoxication from the intake of barium from the diet have been found.

However, in the case of lead, the percentage of contribution is $233 \%$ of the TDI far exceeding the tolerable daily intake value. This is an alarming finding, as lead has multiple toxic effects because it is a carcinogenic, mutagenic metal that damages the developing nervous system [41]. Infants, who these products are intended for, are a highly vulnerable group because they are growing, which is why lead can cause irreversible harmful effects [13]. Although some studies have shown that calcium, due to its similar chemical characteristics, interferes with the absorption of lead at the gastrointestinal level [42], it is necessary to introduce greater controls on these products.

\section{Conclusion}

The content of macroelements ( $\mathrm{Na}, \mathrm{K}, \mathrm{Ca}$ and $\mathrm{Mg}$ ), trace elements ( $\mathrm{Fe}, \mathrm{Cu}, \mathrm{Cr}, \mathrm{Zn}, \mathrm{Mn}, \mathrm{Mo}, \mathrm{Ni}, \mathrm{Li}, \mathrm{B}, \mathrm{Ba}, \mathrm{V}$, and $\mathrm{Sr}$ ) and toxic metals ( $\mathrm{Al}, \mathrm{Cd}$ and $\mathrm{Pb}$ ) were determined in 30 samples of 15 different brands of infant formula by ICP-OES. The study carried out shows that infant formulas meet the macroelement and essential element nutritional needs of infants aged between 6 12 months. The concentration of $\mathrm{Pb}$ found in each of the analyzed samples was higher than the maximum limit established in European legislation. The consumption of these products can 
carry serious risks from a high intake of $\mathrm{Pb}$, which far exceeds the Tolerable Daily Intake (TDI). Therefore, the consumption of these products is not safe. This alarming finding needs to be acted on by the relevant authorities by increasing the controls both on the final products and on the raw materials which are used to make them.

\section{Conflict of interest}

The authors declare that they have no conflicts of interests.

\section{References}

1. Mead MN (2008) Contaminants in Human Milk. Weighing the Risks against the Benefits of Breastfeeding. Environ Health Perspect 116(10): A427-A434.

2. Choi A, Fusch G, Rochow N, Sheikh N, Fusch C (2015) Establishment of micro methods for macronutrient content analysis in breast milk. Matern Child Nutr 11(4): 761-772.

3. O'Connor NR (2009) Infant Formula. Am Fam Phys 79(7): 565-570.

4. Labiner-Wolfe J, Fein SB, Shealy KR (2008) Infant Formula-Handling Education and Safety. Pediatrics 122(2): S85-S90.

5. Koletzko B, Bhutta ZA, Cai W, Cruchet S, El Guindi M, et al. (2013) Compositional Requirements of Follow-Up Formula for Use in Infancy: Recommendations of an International Expert Group Coordinated by the Early Nutrition Academy. Ann Nutr Metab 62(1): 44-54.

6. IOM (Institute of Medicine) (2001) Panel on Micronutrients. 13, Arsenic, Boron, Nickel, Silicon, and Vanadium. In Dietary Reference Intakes for Vitamin A, Vitamin K, Arsenic, Boron, Chromium, Copper Iodine, Iron, Manganese, Molybdenum, Nickel, Silicon, Vanadium, and Zinc. National Academies Press (US), Washington (DC)

7. Rubio C, Paz S, Ojeda I, Gutiérrez AJ, González-Weller D, et al. (2017) Dietary Intake of Metals from Fresh Cage-Reared Hens' Eggs in Tenerife, Canary Islands. J Food Qual 1-10.

8. Gonzalez-Weller D, Rubio C, Gutiérrez AJ, Pérez B, Hérnandez-Sánchez C, et al. (2015) Dietary Content and Evaluation of Metals in Four Types of Tea (White, Black, Red and Green) Consumed by the Population of the Canary Islands. Pharm Anal Acta 6(10): 1-10

9. Moll R, Davis B (2017) Iron, vitamin B12 and folate. Medicine 45(4): 198-203

10. Luis G, Rubio C, Revert C, Espinosa A, González-Weller D, et al. (2015) Dietary intake of metals from yogurts analyzed by inductively coupled plasma optical emission spectrometry (ICP-OES). J Food Comp Ana 39: 48-54.

11. Ikem A, Nwankwoala A, Odueyungbo S, Nyavor K, Egiebor N (2002) Levels of 26 elements in infant formula from USA, UK, and Nigeria by microwave digestion and ICP-OES. Food Chem 77(4): 439-447.

12. Iwegbue CMA, Nwozo SO, Overah LC, Nwajei GE (2010) Survey of trace element composition of commercial infant formulas in the Nigerian market. Food Addit Contam Part B Surveill 3(3): 163-171.

13. Winiarska-Mieczan A (2009) Assessment of infant exposure to lead and cadmium content in infant formulas. J Elementol 14(3): 573-581

14. Brown CJ, Chenery SRN, Smith B, Mason C, Tomkins A, et al. (2004) Environmental influences on the trace element content of teeth implications for disease and nutritional status. Arch Oral Biol 49(9): 705-717.

15. Pors Nielsen S (2004) The biological role of strontium. Bone 35: 583588.

16. González-Weller D, Rubio C, Gutiérrez AJ, Luis González G, Caballero MJM, et al. (2013) Dietary intake of barium, bismuth, chromium, lithium, and strontium in a Spanish population (Canary Islands, Spain). Food Chem Toxicol 62: 856-868.

17. González-Weller D, Gutiérrez AJ, Rubio C, Revert C, Hardisson A (2010) Dietary Intake of Aluminum in a Spanish Population (Canary Island). J Agric Food Chem 58(10): 10452-10457.

18. Hardisson A, Revert C, González-Weller D, Gutiérrez A, Paz S, Rubio C (2017) Aluminium Exposure through the Diet. HSOA JFood Sci Nutr 3(1): 1-10.

19. Rubio C, González-Iglesias T, Revert C, Reguera JI, Gutiérrez AJ, Hardisson A (2005) Lead Dietary Intake in a Spanish Population (Canary Islands). J Agric Food Chem 53(16): 6543-6549.

20. Rubio C, Hardisson A, Reguera JI, Revert C, Lafuente MA, GonzálezIglesias T (2006) Cadmium dietary intake in the Canary Islands, Spain. Environ Res 100: 123-129.

21. Shaheen N, Irfan NMD, Khan IN, Islam S, Islam MDS, et al. (2016) Presence of heavy metals in fruits and vegetables: Health risk implications in Bangladesh. Chemosphere 152: 431-438.

22. Hardisson A, Rubio C, Baez A, Martin M, Alvarez R, Diaz E (2001) Mineral composition of the banana (Musa acuminata) from the island of Tenerife. Food Chem 73(2): 153-161.

23. IUPAC (International Union of Puré and Applied Chemistry) (1995) Nomenclature in Evaluation of Analytical Methods including Detection and Quantification Capabilities. Pure Appl Chem 67: 1699-1723.

24. Rubio C, Napoleone G, Luis-González G, Gutiérrez AJ, González-Weller D, et al. (2017) Metals in edible seaweed. Chemosphere 173: 572-579

25. Gutiérrez A, González-Weller D, González T, Burgos A, Lozano G, et al. (2008) Content of trace metals (iron, zinc, manganese, chromium, copper, nickel) in canned variegated scallops (Chlamys varia). Int J Food Sci Nutr 59(6): 535-543.

26. EC (European Commission) (2006) COMMISSION REGULATION (EC) No 1881/2006 of 19 December 2006 setting máximum levels for certain contaminants in foodstuffs. Off J Eur Union L 364/6.

27. EC (2014) COMMISSION REGULATION (EC) No 488/2014 of 12 May 2014 amending Regulation (EC) No 1881/2006 as regards maximum levels of cadmium in foodstuffs. Off J Eur Union L 138/75.

28. Kazi TG, Jalbani N, Baig JA, Afridi HI, Kandhro GA, et al. (2009) Determination of toxic elements in infant formulae by using electrothermal atomic absorption spectrometer. Food Chem Toxicol 47(7): 1425-1429.

29. Pandelova M, Levy Lopez W, Michalke B, Schramm KW (2012) Ca, Cd, $\mathrm{Cu}, \mathrm{Fe}, \mathrm{Hg}, \mathrm{Mn}, \mathrm{Ni}, \mathrm{Pb}, \mathrm{Se}$, and $\mathrm{Zn}$ contents in baby foods from the $\mathrm{EU}$ market: Comparison of assessed infant intakes with the present safety limits for minerals and trace elements. J Food Comp Anal 27(2): 120127

30. Gundacker C, Pietschnig B, Wittmann KJ, Lischka A, Salzer H, et al.(2002) Lead and mercury in breast milk. Pediatrics 110(5): 873-878.

31. Al-Saleh I, Shinwari N, Mashhour A (2003) Heavy Metal Concentrations in the Breast Milk of Saudi Women. Biol Trace Element Res 96(1-3): 21-37.

32. Rizwan M, Ali S, Adrees M, Ibrahim M, Tsang DCW, Zia-ur-Rehman M et al. (2017) A critical review on effects, tolerance mechanisms and management of cadmium in vegetables. Chemosphere 182: 90-105.

33. FESNAD (Federación Española de Sociedades de Nutrición, Alimentación y Dietética) (2010) Ingestas Dietéticas de Referencia (IDR) para la Población Española. Act Diet 14(4): 196-197.

34. EFSA (European Food Safety Authority) (2009) Scientific Opinion of the Panel on Contaminants in the Food Chain on a request from the European Commission on cadmium in food. EFSA J 980: 1-139. 
35. EFSA (2011) Statement on the evaluation on a new study related to the bioavailability ofaluminum in food. EFSA J 9(5): 2157

36. EFSA (2014) Scientific Opinion on the risks to public health related to the presence of chromium in food and drinking water. EFSA J 12(3): 3595

37. EFSA (2015) Scientific Opinion on the risks to public health related to the presence of nickel in food and drinking water. EFSA J 13(2): 4002

38. WHO (2001) Barium and barium compounds Concise International Chemical Assessment Document, 33. WHO, Geneva, Switzerland.

39. WHO (2011) Strontium and strontium compounds. Concise International Chemical Assessment Document 77: 1-63.
40.AESAN (2012) Report of the Scientific Committee of the Spanish Agency for Food Safety and Nutrition (AESAN) regarding criteria for the estimation of concentrations for the discussion proposals for migration limits of certain heavy metals and other elements from ceramic articles intended to come into content with foodstuffs. J Sci Commit 16: 11-20.

41. EFSA (2010) EFSA Panel on contaminants in the food chain (CONTAM). Scientific opinión on lead in food. EFSA J 8(4): 1570

42. Hong YC, Kulkarni SS, Lim YH, Kim E, Ha M et al. (2014) Postnatal Growth Following Prenatal Lead Exposure and Calcium Intake. Pediatrics 134(6): 1151-1159.

\section{Your next submission with Juniper Publishers} will reach you the below assets

- Quality Editorial service

- Swift Peer Review

- Reprints availability

- E-prints Service

- Manuscript Podcast for convenient understanding

- Global attainment for your research

- Manuscript accessibility in different formats

( Pdf, E-pub, Full Text, Audio)

- Unceasing customer service

Track the below URL for one-step submission https://juniperpublishers.com/online-submission.php 